\title{
Dandy-Walker malformation in methylmalonic acidemia: a rare case report
}

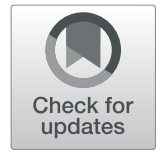

Jingwei Liu', Zhuohang Liu², Haibo Yan' and Yumei Li ${ }^{1 *}$

\begin{abstract}
Background: Methylmalonic acidemia is an organic acid metabolism disorder that usually has nonspecific clinical manifestations.

Case presentation: A 3-month-old female infant was admitted to the hospital for developmental retardation. Her prenatal and birth history was unremarkable. After admission, she developed dyspnea and severe anemia and was subsequently transferred to the intensive care unit. Magnetic resonance imaging of her brain showed a DandyWalker malformation, and metabolic screening indicated methylmalonic acidemia. Thus, she was diagnosed with methylmalonic acidemia and Dandy-Walker malformation. The patient underwent treatment including acidosis correction, blood transfusion, antibiotics, mechanical ventilation and heat preservation. Unfortunately, her condition progressively worsened and she died of metabolic crisis.

Conclusions: Dandy-Walker malformation may be a clinical manifestation of methylmalonic acidemia. Additionally, the co-existence of methylmalonic acidemia and Dandy-Walker malformation may be an uncharacterized syndrome which needs to be studied further.
\end{abstract}

Keywords: Dandy-Walker malformation, methylmalonic acidemia, metabolism disorders

\section{Background}

Methylmalonic acidemia is one of the most common organic acid metabolism disorders. Deficiency in the enzyme methylmalonyl-CoA mutase or adenosylcobalamin synthesis results in inborn errors of metabolism. The clinical manifestations of patients with methylmalonic acidemia are usually nonspecific. Patients with severe methylmalonic acidemia are prone to lethargy, vomiting, respiratory distress, hypothermia, severe ketoacidosis, and hyperammonemia [1]. This condition can impact many parts of the body, and patients commonly display neurological symptoms. The radiological manifestations of methylmalonic acidemia are also nonspecific [2]. Dandy-Walker malformation is a rare neurodevelopmental anomaly, characterized by cystic

\footnotetext{
*Correspondence: liyumei201912@126.com

1 Department of Pediatric Intensive Care Unit, The First Hospital of Jilin University, Xin Min Street, 130021 Changchun, China

Full list of author information is available at the end of the article
}

dilatation of the fourth ventricle, enlargement of the posterior fossa, hypoplasia of the cerebellar vermis, elevated tentorium cerebelli, and hydrocephalus [3, 4]. Dandy-Walker malformation is a rare imaging manifestation, especially in patients with methylmalonic acidemia.

\section{Case presentation}

A 3-month-old female infant was admitted to the hospital for developmental retardation. Her prenatal and birth history was unremarkable. She grew slowly and had a below average height and weight. She could not laugh and raise her head. After admission, she developed dyspnea and severe anemia and was subsequently transferred to the intensive care unit. Auscultation of both lungs indicated some rales. Her lowest body temperature was $34.7^{\circ} \mathrm{C}$, and she developed an irregular respiratory rhythm. Since her condition was progressively worsening, she was treated with invasive mechanical ventilation.

(c) The Author(s). 2021 Open Access This article is licensed under a Creative Commons Attribution 4.0 International License, which permits use, sharing, adaptation, distribution and reproduction in any medium or format, as long as you give appropriate credit to the original author(s) and the source, provide a link to the Creative Commons licence, and indicate if changes were made. The images or other third party material in this article are included in the article's Creative Commons licence, unless indicated otherwise in a credit line to the material. If material is not included in the article's Creative Commons licence and your intended use is not permitted by statutory regulation or exceeds the permitted use, you will need to obtain permission directly from the copyright holder. To view a copy of this licence, visit http://creativecommons.org/licenses/by/4.0/ The Creative Commons Public Domain Dedication waiver (http://creativecommons.org/publicdomain/zero/1.0/) applies to the data made available in this article, unless otherwise stated in a credit line to the data. 
Routine blood examination showed normal leukocyte and platelet counts, an erythrocyte count of $1.04 \times 10^{12} /$ $\mathrm{L}$, and a hemoglobin level of $33 \mathrm{~g} / \mathrm{L}$. After a blood transfusion, her hemoglobin gradually increased to a normal level. Blood gas analysis revealed an elevated lactic acid level of $14.62 \mathrm{mmol} / \mathrm{L}$, a decreased $\mathrm{pH}$ of 6.84 , partial pressure of carbon dioxide of $74.70 \mathrm{mmHg}$, partial pressure of oxygen of $21.50 \mathrm{mmHg}$, and potassium level of $6.3 \mathrm{mmol} / \mathrm{L}$. Her C-reactive protein level was $18.40 \mathrm{mg} /$ L. A chest radiograph showed a patchy dense shadow in both lungs. She was also positive for cytomegalovirus immunoglobulin $\mathrm{M}$ antibody. Magnetic resonance imaging of her brain showed cerebellar vermis hypoplasia, enlargement of the fourth ventricle, and supratentorial hydrocephalus (Fig. 1). In consultation with the neurosurgery department, it was determined that there was no need for surgical treatment for the time being. The patient's guardian refused to complete genetic and chromosome analysis. Although the patient received therapy. including acidosis correction with sodium bicarbonate, blood transfusion, antibiotics, mechanical ventilation, and heat preservation, she died 4 days after admission due to metabolic crisis. After her death metabolic screening showed elevated methylmalonic acid and methyl citrate levels.

\section{Discussion and conclusion}

Here, we report a case of methylmalonic acidemia in a patient with a Dandy-Walker malformation. To the best of our knowledge, this brain imaging finding is very rare in patients with methylmalonic acidemia. Most cases of Dandy-Walker malformations are reported in infants below the age of 1 year [5], although sometimes, diagnosis may also be delayed until adulthood [6]. This malformation affects approximately $1 / 25,000-30,000$ newborns [7], and some patients are asymptomatic [6]. DandyWalker malformation may develop in isolation or occur as part of a chromosomal abnormality or Mendelian disease [8]. Developmental arrest of the hindbrain before

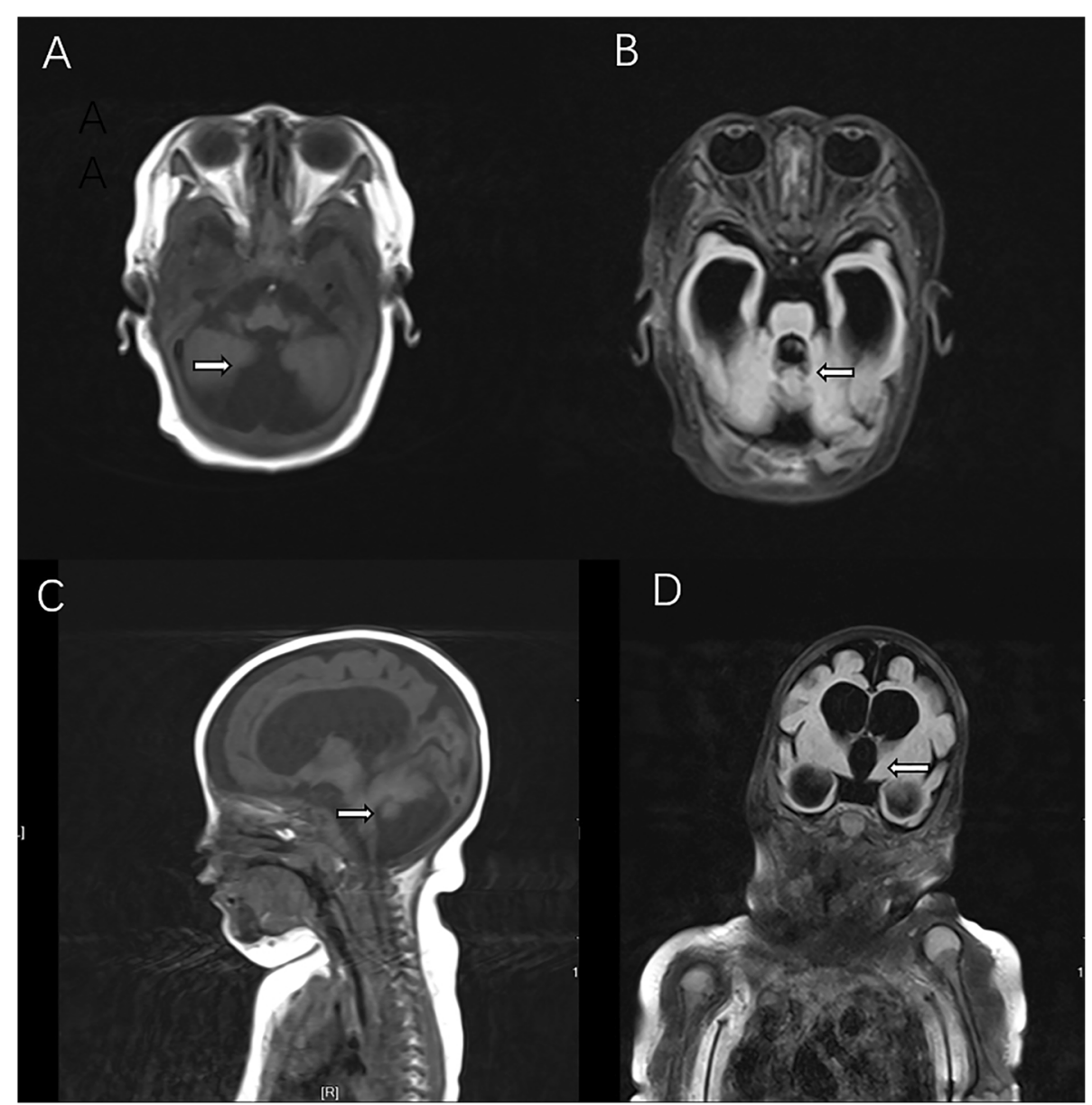

Fig. 1 Magnetic resonance imaging of the brain demonstrated cerebellar vermis hypoplasia, enlargement of the fourth ventricle and supratentorial hydrocephalus. Axial T1 weighted imaging (A), Axial T2 weighted imaging with fat and fluid suppression (B), Sagittal T1-weighted imaging (C), Coronal T2 weighted imaging with fat and fluid suppression (D) 
the third month is the most convincing etiological theory for Dandy-Walker malformation. Chromosomal abnormalities and single-gene diseases are the etiologies of Dandy-Walker malformation [9].

Methylmalonic acidemia is a severe and even lifethreatening metabolic disease. Methylmalonic acid is produced during the metabolism of some odd-chain fatty acids and amino acids. Methylmalonic acidemia is caused by defects in methylmalonyl-CoA mutase or its coenzyme [2]. The incidence rate of methylmalonic acidemia varies from region to region. One study showed that the incidence of methylmalonic acidemia was $1 /$ 51,100 [10]. This disease can involve many parts of the body. Some complications of methylmalonic acidemia include chronic kidney disease [11], diffuse lung disease secondary to methylmalonic acidemia [12], and pulmonary artery hypertension $[13,14]$. Pancytopenia and bone marrow hypoplasia may also occur in patients with methylmalonic acidemia during metabolic crises, and this phenomenon correlates with the organic acid concentration [15]. Cerebral and cerebellar atrophy, hypomyelination, reactive gliosis, depletion or hypoplasia of extracerebellar granulosa cells, and multifocal cerebellar hemorrhage are all neuropathologic changes observed in children with methylmalonic acidemia [2]. The main magnetic resonance imaging manifestations of patients with methylmalonic acidemia include cerebral atrophy, white matter abnormalities, ventricular dilatation, and corpus callosal thinning [16]. Our patient developed anemia, metabolic acidosis, respiratory failure, hyperlactatemia, pneumonia, and hypothermia associated with methylmalonic acidemia.

Our patient was positive for cytomegalovirus immunoglobulin $\mathrm{M}$ antibody. We are unsure whether the cytomegalovirus infection was congenital due to the lack of cytomegalovirus testing during the neonatal period. The patient had never received anti-cytomegalovirus treatment. Congenital cytomegalovirus infection usually leads to neurologic conditions in children [17]. Prenatal cytomegalovirus infection is a secondary condition of cerebellar hypoplasia [18]. One limitation of this case is that we lack whole exome sequencing and chromosomal "analysis, which may have helped explain the presence of both methylmalonic acidemia and Dandy-Walker malformation in this patient.

Our case highlights a rare association between methylmalonic acidemia and Dandy-Walker malformation. The co-existence of Dandy-Walker malformation and methylmalonic acidemia may be a yet uncharacterized syndrome. It is possible that Dandy-Walker malformation is just a special manifestation of methylmalonic acidemia or alternately was caused by a congenital infection in our patient with methylmalonic acidemia. Regardless, this association merits further study.
Abbreviations

IgM: Immunoglobulin M; CoA: coenzyme A

Acknowledgements

Not applicable,

\section{Authors' contributions}

$Y L$ and $J L$ designed the report. $J L$ wrote the paper. $Z L$ and $H Y$ collected and assembled patient data. All authors read and approved the final manuscript.

Funding

Not applicable.

Availability of data and materials

Data sharing is not applicable to this article as no datasets were generated or analyzed during the current study. Data are available from the corresponding author upon request.

\section{Declarations}

\section{Ethics approval and consent to participate}

The case report has been approved by the ethics committee of The First Hospital of Jilin University (2021 - 510). The requirement for consent to participate was abandoned in accordance with the rules of The First Hospital of Jilin University ethics committee.

\section{Consent for publication}

Written informed consent was obtained from the parents for publication of this case report.

\section{Competing interests}

The authors declare that they have no competing interests.

\section{Author details}

${ }^{1}$ Department of Pediatric Intensive Care Unit, The First Hospital of Jilin University, Xin Min Street, 130021 Changchun, China. ${ }^{2}$ Department of Radiology, The First Hospital of Jilin University, Changchun, China.

Received: 24 June 2021 Accepted: 2 September 2021

Published online: 13 September 2021

\section{References}

1. Chandler RJ, Venditti CP. Gene Therapy for Methylmalonic Acidemia: Past, Present, and Future. Hum Gene Ther2019 Oct;30(10):1236-44.

2. Radmanesh A, Zaman T, Ghanaati H, Molaei S, Robertson RL, Zamani AA. Methylmalonic acidemia: brain imaging findings in 52 children and a review of the literature. Pediatric radiology2008 Oct;38(10):1054-61.

3. Trehout M, Zhang N, Blouet M, Borha A, Dollfus S. Dandy-Walker Malformation-Like Condition Revealed by Refractory Schizophrenia: A Case Report and Literature. Review Neuropsychobiology. 2019;77(2):59-66.

4. ten Donkelaar HJ, Lammens M, Wesseling P, Thijssen HO, Renier WO. Development and developmental disorders of the human cerebellum. J Neurol2003 Sep;250(9):1025-36.

5. Kumar R, Jain MK, Chhabra DK. Dandy-Walker syndrome: different modalities of treatment and outcome in 42 cases. Childs Nerv Syst2001 May;17(6):348-52.

6. Jha VC, Kumar R, Srivastav AK, Mehrotra A, Sahu RN. A case series of 12 patients with incidental asymptomatic Dandy-Walker syndrome and management. Childs Nerv Syst2012 Jun;28(6):861-7.

7. Venturini E, Magni L, Pucci G, Mazzinghi F. A late presentation of DandyWalker malformation and aortic coarctation. J Cardiovasc Med (Hagerstown)2017 May; 18(5):381-84.

8. Bosemani T, Orman G, Boltshauser E, Tekes A, Huisman TA, Poretti A. Congenital abnormalities of the posterior fossa. Radiographics: a review publication of the Radiological Society of North America, Inc2015 Jan-Feb; 35(1):200-20

9. Wang LM, Zhang M, Wang PP, Zhou XG, Piao YS, Lu DH. A Dandy-Walker malformation associated with ganglioglioma. Chin Med J (Engl)2019 Oct 20; 132(20):2495-97.

10. Shigematsu Y, Hirano S, Hata I, Tanaka Y, Sudo M, Sakura N, et al. Newborn mass screening and selective screening using electrospray tandem mass 
spectrometry in Japan. Journal of chromatography B, Analytical technologies in the biomedical and life sciences2002 Aug 25;776(1):39-48,

11. Charuvanij S, Pattaragarn A, Wisuthsarewong W, Vatanavicharn N. Juvenile gout in methylmalonic acidemia. Pediatr Int2016 Jun;58(6):501-03.

12. Liu J, Peng Y, Zhou N, Liu X, Meng Q, Xu H, et al. Combined methylmalonic acidemia and homocysteinemia presenting predominantly with late-onset diffuse lung disease: a case series of four patients. Orphanet J Rare Dis2017 Mar 21;12(1):58.

13. Kido J, Mitsubuchi H, Sakanashi M, Matsubara J, Matsumoto S, Sakamoto R, et al. Pulmonary artery hypertension in methylmalonic acidemia. Hemodial Int2017 Apr;21(2):E25-E29.

14. Liao HY, Shi XQ, Li YF. Metabolic and genetic assessments interpret unexplained aggressive pulmonary hypertension induced by methylmalonic acidemia: A case report. World J Clin Cases2020 Mar 26;8(6):1137-41.

15. MacFarland S, Hartung H. Pancytopenia in a patient with methylmalonic acidemia. Blood2015 Mar 12;125(11):1840.

16. Yang L, Guo B, Li X, Liu X, Wei X, Guo L. Brain MRI features of methylmalonic acidemia in children: the relationship between neuropsychological scores and MRI findings. Sci Rep2020 Aug 4;10(1):13099.

17. De Catte L, De Keersmaeker B, Claus F. Prenatal neurologic anomalies: sonographic diagnosis and treatment. Paediatric drugs2012 Jun 1;14(3):143-55.

18. Poretti A, Boltshauser E, Doherty D. Cerebellar hypoplasia: differential diagnosis and diagnostic approach. Am J Med Genet C Semin Med Genet2014 Jun;166 C(2):211-26.

\section{Publisher's Note}

Springer Nature remains neutral with regard to jurisdictional claims in published maps and institutional affiliations.

Ready to submit your research? Choose BMC and benefit from:

- fast, convenient online submission

- thorough peer review by experienced researchers in your field

- rapid publication on acceptance

- support for research data, including large and complex data types

- gold Open Access which fosters wider collaboration and increased citations

- maximum visibility for your research: over $100 \mathrm{M}$ website views per year

At $\mathrm{BMC}$, research is always in progress.

Learn more biomedcentral.com/submissions 